\title{
ROS1 Gene Rearrangement Negative
}

National Cancer Institute

\section{Source}

National Cancer Institute. ROS1 Gene Rearrangement Negative. NCI Thesaurus. Code C147054.

A genetic finding indicating that rearrangement of the ROS1 gene has not been detected in a sample. 